\title{
Correspondence
}

Journal of Medical Genetics, 1978, 15, 317-320

\section{Computerised chromosome data bank}

SIR,

I was preparing the material contained in the excellent report by Martin et al. (1977) of mosiac trisomy 14 in a liveborn infant for entry into my computerised data bank of Catalog of Chromosomal Variations and Anomalies in Man (Borgaonkar, 1975, 1977a), and came across this sentence: 'We report here a liveborn infant whose complement was $46, \mathrm{XX} / 47, \mathrm{XX},+14$, the first such case reported to our knowledge'. The claim may indeed be justified, but if it implies that this is the first report of such a case in the literature then it is misleading. Rethore et al. (1975) have also reported a mosaic trisomy 14 newborn female infant.

I have pointed out elsewhere similar instances of misleading claims (Yu et al., 1976; Borgaonkar, 1977b) and have desisted from pointing out many others.

What is needed is a central data bank wherein the reports of chromosomal variants and anomalies are filed appropriately. Such a facility could then be called upon to provide service to investigators in bibliographic citations. This facility would be somewhat like the National Library of Medicine (USA) projects of MEDLINE, MEDLAR, and TOXLINE. Our data banks have been used by many cytogeneticists around the world precisely for that purpose. Additionally, such a facility, if properly directed, could be used in collating data which may be helpful in providing the descriptions of new chromosomal syndromes, as has been done by Martin et al. (1977), by us (Borgaonkar et al., 1976), and by several authors (Yunis, 1977). Yours, etc,

DigAMBER S. BORGAONKAR Division of Medical Genetics, Department of Medicine,

The Johns Hopkins University School of Medicine, Baltimore, Maryland 21205,

USA

\section{References}

Borgaonkar, D. S. (1975). Chromosomal Variation in Man. A Catalog of Chromosomal Variants and Anomalies. The Johns Hopkins University Press, Baltimore and London.

Borgaonkar, D. S. (1977a). Chromosomal Variation in Man A Catalog of Chromosomal Variants and Anomalies, 2nd ed. Alan R. Liss, New York.
Borgaonkar, D. S. (1977b). $\mathrm{Y}$ to $\mathrm{X}$ chromosome translocations. Human Genetics. 40, 113-114.

Borgaonkar, D. S., Lacassie, Y. E., and Stoll, C. (1976). Usefulness of chromosome catalog in delineating new syndromes. Birth Defects: Original Article Series, 12 (No. 5), 87-95. The National Foundation-March of Dimes, New York.

Martin, A. O., Ford, M. M., Khalil, N. T., Turk, K. B., and MacIntyre, M. N. (1977). 46, XX/47, XX, +14 mosaicism in a liveborn infant. Journal of Medical Genetics, 14, 214-218.

Rethoré, M. O., Couturier, J., Carpentier, S., Ferrand, J., and Lejeune, J. (1975). Trisomie 14 en mosaique chez une enfant multimalformée. Annales de Génétique, 18, 71-74.

Yu, C. W., Borgaonkar, D. S., and Bolling, D. R. (1976) Paracentric inversion in man. Human Genetics, 34, 117.

Yunis, J. J. (Editor) (1977). New Chromosomal Syndromes. Academic Press, New York.

\section{Heterozygote advantage for the phenylketonuria allele}

SiR,

Further to the correspondence on heterozygote advantage for the phenylketonuria gene, though individual women tend to have pregnancies of similar gestational length, birthweight usually increases with parity. The increase is determined by the sex of the previous, as well as the later, child, and is usually greatest in the second pregnancy (Karn et al., 1951; Trotnow et al., 1976). When pregnancy is allowed to proceed naturally, mean increase between first and second child equals the discrepancy in birthweight between the sexes (approximately $140 \mathrm{~g}$ ). This is the case in present day Norway and Denmark, less so in Scotland and Germany, and in USA mean increase is negligible (Table). In England, no information is available after 1958 concerning mean increase between first and second child. The $138 \mathrm{~g}$ mean increase between the first and later-born in England in 1970 is of uncertain importance, since we have no information concerning the magnitude of the increase in birthweight between consecutive later pregnancies. According to Baird (1976), the policy of induction, aimed at forestalling death, was determined by the epidemiological findings in Aberdeen in the late 1940s when more than $20 \%$ of all first births were to women 30 years of age or more. In addition $40 \%$ of all perinatal deaths in first pregnancy were the result either of birth trauma or of placental insufficiency, and the pregnancy had lasted 42 weeks or more in more than 
Table Mean increase in birthweight with parity in selected countries

\begin{tabular}{|c|c|c|c|c|c|}
\hline Country & Year & $I-I I$ & $I I-I I I$ & $I I I-I V$ & IV-later \\
\hline $\begin{array}{l}\text { Norway }^{1} \\
\text { Denmark }^{1} \\
\text { England }^{2}\end{array}$ & $\begin{array}{l}1967 \\
1970 \\
1935-46 \\
1958 \\
1970\end{array}$ & $\begin{array}{l}140 \mathrm{~g} \\
150 \mathrm{~g} \\
145 \mathrm{~g} \\
140 \mathrm{~g}\end{array}$ & $\begin{array}{r}40 \mathrm{~g} \\
<50 \mathrm{~g} \\
27 \mathrm{~g}\end{array}$ & $\begin{array}{r}40 \mathrm{~g} \\
<50 \mathrm{~g}\end{array}$ & $\begin{array}{l}10 \mathrm{~g} \\
\mathrm{I} \text {-later } \\
138 \mathrm{~g}\end{array}$ \\
\hline $\begin{array}{l}\text { Scotland }{ }^{3} \\
\text { Germany }{ }^{4} \\
\text { New York State } \\
\text { (white births) }\end{array}$ & $\begin{array}{l}1969-73 \\
1966-71 \\
1959-67\end{array}$ & $\begin{array}{r}120 \mathrm{~g} \\
104 \mathrm{~g} \\
59 \mathrm{~g}\end{array}$ & $\begin{array}{r}<10 \mathrm{~g} \\
39 \mathrm{~g} \\
29 \mathrm{~g}\end{array}$ & $\begin{array}{r}-20 \mathrm{~g} \\
12 \mathrm{~g} \\
11 \mathrm{~g}\end{array}$ & \\
\hline USA $^{6}$ & 1973 & $50 \mathrm{~g}$ & $10 \mathrm{~g}$ & $10 \mathrm{~g}$ & \\
\hline
\end{tabular}

Information from: 'Medical Registration of Births in Norway and Denmark; ${ }^{2} \mathrm{Karn}$ et al. (1951); ${ }^{3} \mathrm{~A}$. F. Lewis, 1977, personal communication; ${ }^{4} \mathrm{Trotnow}$ et ak $\overrightarrow{\vec{\omega}}$ (1976); 'Selvin and Janerich (1971); ${ }^{\circ}$ Vital Health Statistics, Vol. 1, Natality, 1973.

$40 \%$ of the cases in both groups. Baird, however, did not advocate wholesale induction. In Scandinavia today, as well as in England, the mothers are younger and healthier than a generation ago, and for this reason the dangers of prolonged pregnancy are less. Possibly, therefore, there is less medical reason for induction today. However, the proportion of elective delivery is continuously increasing and there is reason to believe that those women most at risk of being induced are the uncomplicated high birthweight pregnancies of upper and middle class women (Niswander and Gordon, 1972). Usually, these women have easier access to innovations in medical practice than lower class populations. The reduction in heavy newborn babies $(>3500 \mathrm{~g})$ may therefore be greater than expected from a level of elective delivery around $40 \%$. In view of the known inaccuracy of the menstrual history in at least $20 \%$ of women, and the tendency for individual mothers to have pregnancies of similar gestational length, we would expect elective delivery more often in second and later pregnancies. That is to say, we would expect minimal effect on birthweight and duration of pregnancy among firstborn infants. However, during 1965 to 1974, mean birthweight and gestational age at delivery among firstborn infants of Cardiff residents fell appreciably. The fall in birthweight was considered secondary to the fall in gestational age (Newcombe and Chalmers, 1977). Between 1970 and 1974 mean gestational age was 39.575 weeks, as compared with 40.15 weeks among all singletons certain of dates in Britain in 1970 (Chamberlain et al., 1975), and in Norway between 1967 and 1971 (Saugstad, 1978a,b). More particularly, the present discrepancy in weight of male and female firstborns in Norway is of the order of some 130 to $140 \mathrm{~g}$, and the distribution by gestational age differs significantly with a striking excess of female post-term deliveries (Saugstad, 1978b). We, therefore, expect the overall shorter mean duration of gestation, such as observed in Cardiff, to affect the discrepancy in birthweight between the sexes.
Concerning a continuation of the secular downwardr trend in birthweight observed in England between ${ }^{\circ}$ 1958 and 1970, it ought to be mentioned that owing to the adverse effect on mean increase with parity of widespread use of elective delivery, the reducing effec5 on birthweight of declining parity may be less important than expected. This is reported from the USA where between 1960 and 1973 mean parity declined from 2.92 to 2.13 , but the effect on birth $\frac{\bar{C}}{\infty}$ weight was negligible $(10 \mathrm{~g}$ or so). It would have approached $50 \mathrm{~g}$ with similar increase in birthweight $\vec{\odot}$ with parity in Norway and Denmark (Saugstad, 1978b).

As regards the later pregnancies of heterozygotes? for PKU, who have already given birth to a PKU homozygote, labour is likely to be induced moreळ frequently than usual, if not terminated by an abortion $\bar{D}$ Yours, etc, LETTEN FEgERSTEN SAUGSTAD EEG Laboratory, Kyrre Greppagt 11, Oslo 4: Norway

\section{References}

Baird, D. (1976). Induction of labour. British Medical Journal, $1,896$.

Chamberlain, R. G., Chamberlain, G., Howlett, B., and Claireaux, 은 A. (1975). The first week of life. In British Births, 1970, Vol. 1, p. 278. Heinemann, London.

Karn, M. N., Lang Brown, H., MacKenzie, H., and Penrose, L. S. (1951). Birth weight, gestation time and survival in sibs. $N$ Annals of Eugenics, 15, 306-322.

Newcombe, R., and Chalmers, I. (1977). Changes in distribution $N$ of gestational age and birth weight among first born infants of Cardiff residents. British Medical Journal, 2, 825-826.

Niswander, K. R., and Gordon, M. (1972). The Women and their Pregnancies. The Collaborative Perinatal Study. Saunders Philadelphia.

Saugstad, L. F. (1978a). 'Domestication of Man' within reach in Scandinavia today. Population Studies. (Submitted.)

Saugstad, L. F. (1978b). Distribution by weight of all births, trend $\square$ in birthweight and infant mortality in selected countries. Annals $\bar{O}$ of Human Genetics. (Submitted.) 
Selvin, S., and Janerich, D. T. (1971). Four factors influencing birthweight. British Journal of Preventive and Social Medicine, 25, $12-16$.

Trotnow, S., Bregulla, K., and Flügel, K. (1976). Untersuchung über die Körpergrösse und das Körpergewicht con Neugeborenen in Abhängigkeit vom Paritätsstatus. Geburtshilfe und Frauenheilkunde, 36, 744-750.

\section{Complete trisomy 5p}

SIR,

In their recent report on 'Complete trisomy 5p', Brimblecombe et al. (1977) imply that the phenotype in partial trisomy $5 p$ is nonspecific, and that asymmetry of the jaw is a common finding. In our recent review on partial trisomy $5 \mathrm{p}$, we suggested that there was a recognisable and consistent phenotype based on a review of published cases and 3 additional patients of our own (DiLiberti et al., 1977). The consistent findings include a full face with the appearance of jowls, apparent ocular hypertelorism, bulbous nose, long philtrum, full lips with down-turned corners of the mouth, and mild malar hypoplasia. Asymmetry of the jaw was infrequent. It is of interest that the photograph of the patient of Brimblecombe et al. suggests most of these features and, in fact, with the exception of the ear and eye anomalies, looks remarkably like several of the young patients with partial trisomy $5 \mathrm{p}$.

Additional features present in most patients were an excess of ulnar loops, arch tibial patterns in the hallucal area, and seizures. None of these is commented upon in the current report.

Since the majority of patients with partial trisomy $5 p$ lack significant malformations, it is tempting to speculate that the extra chromosomal material distal to band p13 produces the characteristic facial appearance and retardation, and that the more proximal portion is responsible for the structural abnormalities of the eye and ear.

$$
\begin{array}{r}
\text { Yours, etc, } \\
\text { JoHN H. DiLiBERTI } \\
\text { Department of Pediatrics, } \\
\text { University of Oregon Health Sciences Center, } \\
3181 \text { SW Sam Jackson Park Road, } \\
\text { Portland, Oregon 97201, USA. }
\end{array}
$$

\section{References}

Brimblecombe. F. S. W., Lewis, F. J., and Vowles, M. (1977). 'Complete 5p' trisomy: 1 case and 19 translocation carriers in 6 generations. Journal of Medical Genetics, 14, 271-274.

DiLiberti, J. H., McKean, R. Webb, M. J., and Williams, G. (1977). Trisomy 5p: delineation of clinical features. Birth Defects: Original Article Series, 13, 3C, 185-194.

This letter was shown to Drs Brimblecombe and Vowles who reply as follows:
SIR,

Thank you for the opportunity to reply to the letter of Dr DiLiberti. Despite the fact that DiLiberti et al. (1977) suggest that there is a clinically indentifiable syndrome for partial trisomy $5 p$, we still maintain that there appears to be some overlap in the clinical findings described in trisomy of the short arms of chromosomes 4 and 5.

Owen et al. (1974) compared the clinical features of 1 definite and 1 probable previously described cases of trisomy of the short arm of chromosome 4 with those of their own case. Darmady and Seabright (1975) described a further case involving most of the short arm of this same chromosome. Each of these 4 cases had between 1 and 4 of the following features described by DiLiberti et al. (1977): ocular hypertelorism, bulbous nose, long philtrum, impaired mobility of elbow joints, high dermal ridge count, and mental retardation. Furthermore, they each had between 3 and 6 different features in common with our case of total trisomy 5, such as scaphocephaly, macroglossia, malformed ears, microphthalmia, narrow palpebral fissures, long fingers and toes, scoliosis, and talipes.

Tempting though it is to speculate that certain phenotypic characteristics can be assigned to different portions of the chromosome, we do not feel that this is justified as yet in the light of the above observations. Yours, etc,

F. S. W. BRIMBLECOMBE AND M. VOWLES Department of Paediatrics, Royal Devon and Exeter Hospital (Heavitree), Gladstone Road, Exeter EX1 2ED.

\section{References}

Darmady, J. H., and Seabright, M. A. (1975). A family with an inherited translocation involving the no. $4 /$ no. 21 chromosomes. Journal of Medical Genetics, 12, 408-411.

DiLiberti, J. H.. McKean, R., Webb, M. J., and Williams, G. (1977). Trisomy 5p: delineation of clinical features. Birth Defects: Original Article Series, 13, 3C, 185-194.

Owen, L., Martin, B., Blank, C. E., and Harris. F. (1974). Multiple congenital defects associated with trisomy for the short arm of chromosome 4. Journal of Medical Genetics, 11, 291-295.

\section{Dominance in human genetics}

The following letter from Professor E. B. Ford, FRS, arises from a definition of dominance which appears in the glossary of 'Human Genetics and Medicine' by C. A. Clarke (1977). This reads: 'Dominance: A character is said to be dominant if the gene controlling it produces the same effect in the heterozygous as in the homozygous state. Loosely, however, for clinical purposes, a condition is said to be dominant if it appears in heterozygotes. The homozygote has often never been observed'. 